\title{
The Positive-Externality of Property Right and the Property Right-Regulation: Take the Grain Production-Regulation of Land Use as an Example
}

\author{
Beiwei Liu' ${ }^{1}$ Zhengfeng Liu² \\ ${ }^{1}$ Economics Department of School of Social Sciences of College of Humanities, Arts, and Social Sciences of Nanyang \\ Technological University, Singapore, Singapore \\ ${ }^{2}$ Society Development College of Yangzhou University, Yangzhou, China \\ Email: LIUB0023@e.ntu.edu.sg
}

How to cite this paper: Liu, B. W., \& Liu, Z. F. (2020). The Positive-Externality of Property Right and the Property Right-Regulation: Take the Grain Production-Regulation of Land Use as an Example. Open Journal of Social Sciences, 8, 455-470.

https://doi.org/10.4236/jss.2020.83038

Received: February 14, 2020

Accepted: March 28, 2020

Published: March 31, 2020

\begin{abstract}
Property right also has positive-externality. The beneficial object of positive-externality of property right is society rather than property owner. The private income of individual economic efforts is separated from social income. The positive-externality of property rights is subject to the use of property rights, economic and social development, and the people's cognitive ability and cognitive level, and has the characteristics of time difference and historical dynamics. The significant Positive-Externalities of property rights are consistent with the public policy objectives. In order to maximize the realization of the public policy objectives and ensure the scale of production mode with significant Positive-Externalities, the government takes Suppressive-Regulation over related property rights and limits the use of related assets to specific categories or scopes. In order to ensure the level of investment in the production mode of property rights with significant positive-externality, the government adopts Incentive-Regulation over relevant property rights and grants certain economic incentives to the specific use of relevant assets. The positive-externality of property rights not only provides the root of legitimacy for both suppressive property rights regulation and incentive property rights regulation. A single Suppressive-Regulation of property rights may not effectively guarantee the sustainable reproduction of production mode with significant Positive-Externalities, which requires the coordination of incentive property rights regulation. Incentive-Regulation does not necessarily have the effect of promoting the sustainable expansion and reproduction of production mode with significant Positive-Externalities.
\end{abstract}


Legal incentive property right regulations with sufficient benefits can effectively correct the market failure of production mode with significant positive-externality and promote the sustainable extended reproduction of production mode with significant Positive-Externalities. Property right regulation is a public policy tool serving the public policy objectives, but whether the public policy objectives can be achieved depends on the accuracy of the property right regulations, that is, Whether the definition of the object of control as property right Suppressive-Regulation and property right Incentive-Regulation is accurate, whether the regulating intensity is sufficient, and whether the regulating measures conform to the principle of modern rule of law, Neither too abstract nor too concrete.

\section{Keywords}

Positive-Externality, Property Right Regulation, Suppressive-Regulation, Incentive-Regulation

\section{Introduction}

The existing literature mostly discusses regulation under the concept and framework of negative externality, which is attributed to the root of inhibitory regulation. Search the Journal Database of CNKI, by the end of February 29, 2020, there are 6 articles with negative externalities and regulation concepts, including 2 core journals and CSSCI journals, but no one article with Positive-Externalities and regulatory concepts. We can find 21 articles with regulation in title and negative externalities in keywords, including 15 Peking University core and CSSCI journals, 27 articles with regulation in title and with negative externalities in abstracts, including 13 Peking University core and CSSCI journals; But there are only 2 articles with regulation and Positive-Externalities in the title, including 1 Peking University core and CSSCI journal, and 8 articles with regulation and Positive-Externalities in the title, including 4 Peking University core and CSSCI journals. There are 9 regulatory documents contain the concept of regulation in the title, at the same time, the keywords or abstract also contain the Positive-Externalities, but there are 48 regulatory documents whose title contains regulation contain the negative externalities in keywords or in the abstract. The former is about $1 / 5$ of the latter. This data shows that the Positive-Externalities have not attracted enough attention of regulatory documents.

In the regulatory literature on Positive-Externalities, there are 3 core journals and CSSCI literature in total, among these literatures, Feng Juncheng (Feng, 2017) discussed the Positive-Externalities of foreign-funded enterprises in investment attraction and their softening effect on environmental law enforcement of foreign-funded enterprises; Tian Shuying (Tian, 2010) discussed the positive and negative externalities of forestry management behavior, advocated different treatment, and adopted compulsory regulation for negative ex- 
ternalities and Incentive-Regulation for Positive-Externalities; Zhang Lixiang and Zhang Xicai (Zhang, 2011) discussed that the industrial links of seedling, processing and sales in the agricultural industrial chain are the key links with greater Positive-Externalities, and advocated that the key point of government regulation should be to improve the industrial policies of these key industrial links. These documents discuss the relationship between positive-externality and Incentive-Regulation, provide the legitimacy support of positive-externality for Incentive-Regulation, and propose the accuracy of Incentive-Regulation. The regulation includes Suppressive-Regulation and Incentive-Regulation. The former includes price regulation, rate of return regulation, market access, merger and acquisition restriction, pollution control, etc (Dou \& Li, 2017); the latter includes publicity, reward, subsidy, etc. (Tian, 2010).

The discussion of the relationship between positive-externality and regulation in the existing literature raises a question for us, that is whether positive-externality has applicable space for Suppressive-Regulation, whether Incentive-Regulation has institutional performance that inevitably promotes positive-externality economic efforts, and whether Suppressive-Regulation and Incentive-Regulation are compatible with each other and serve the same public policy goal together? This paper tries to discuss.

\section{Positive-Externality and Property Right Suppressive-Regulation}

Property rights consist of the right or power to consume, receive income from and assign certain assets (Barzel, 1997). People's property right to specific assets is not a right or power, but a bunch of rights or powers, which generally consists of the right to use, the right to gain and the right to trade. Property rights are divisible and transferable. The divisibility of property rights enables the right bundle of property rights can to be decomposed and reorganized in innumerable ways according to the wishes of individuals or the agreement of both parties of transaction. It can be said that How rich is human imagination, how rich is the decomposition and reorganization of property rights. Different subjects of property rights may own one or several rights or powers over the same asset, such as the right of to use, the right to gain or the right to trade. All rights of the same asset may also belong to the same property owner or multiple property owners. In this way, different matching and combination relations will be formed among the rights of the same asset, i.e. the property right subject structure (Ji, 2010). The transferability of property right enables the subject of property right to freely transfer the property right within its remaining property right period within the scope of not more than the rights of the transferor and no violation of the obligations agreed by the transferor. The target direction of the new subject of property right may be the same as or different from that of the original subject of property right, that is, the target direction of property right is diverse, i.e. the property right direction structure. 


\subsection{Positive-Externality of Property Rights and Private Suppressive-Regulation of Property Right}

Property in common law can be divided into ownership, real estate, movable property and lease. Ownership includes full ownership and incomplete ownership. Incomplete ownership includes the division of the same thing between different subjects at the same time, the division of the same thing between different subjects at different times, and the division of one or more combined powers of full ownership. Real estate includes existing real right and expectant real right. Expectant real right originates from the division of ownership in time (Michael, 1996). Incomplete ownership and expectant real right are set mostly by the full owner and related interest subject based on the free and true meaning. People in the real world have their own pursuits, some pursue the maximization of economic interests, some pursue the peace of soul or spiritual interest, some give consideration to both the economic interests and the spiritual interests, some pursue other interests. Therefore, the use of property right also has some Positive-Externalities to specific stakeholders. For example, Zhang inherited a piece of land from his grandfather, $\mathrm{Li}$, and became the complete owner of the land. Grandpa had been planting wheat and corn on the land before. Zhang had deep feelings with his grandfather. Zhang rented all the inherited land to Wang. In the lease, Zhang Limited Wang to plant wheat and corn, and could not change the land use to plant rice or others, as we can see, the use of this land for wheat and corn planting has a positive-externality beneficial for Zhang. This is a positive-externality for a specific individual. Zhang's value goal for this land is not the same as Wang's. Wang's pursuit is to maximize his personal economic interests. When planting wheat and corn can't bring Wang's expected interests, Wang will seek Zhang's consent to plant others or terminate the lease. Wang can continue to lease Zhang's land for wheat and corn only when planting wheat and corn can meet his minimum expected interests Rice planting. As a result, the use of real right by the existing property owner is restricted by the full owner or the power division agreement, or the power transfer agreement.

As a result, the use of real right by the existing property owner is restricted by the full owner or the power division agreement, or the power transfer agreement. Therefore, assets have different property right structures and corresponding economic and social benefits. The existing use of assets is only one or several of the existing ways of use. The existing way of use may be but not necessarily be the most economic and efficient way of use. The use of assets by the existing property owner is subject to the restriction of the full owner or the agreement of power division and power transfer, which is the basis of the existing property owner to the transferor and the authorizer according to the obligation of private law, the property right of the existing property owner to the assets is therefore the property right with limited scope, which is called "Intentional Use Suppressive Property Right" in this paper. The restrictions on the use of assets by the property owner are not only from the restrictions of the full owner and the fore- 
hand, but also from the restrictions of the law. The former is set by the full owner or the forehand in the way agreed in the contract, which depends on the free will of both parties. In this paper, the property regulation similar to the independent creation of the property owner through the contract is called "Use Intentional Suppressive Property Right Regulation", the scope of property right regulation is not limited to the use of property right; the latter comes from the direct provisions of the law, which is called "Use Legal Suppressive Property Right' in this paper. Because it is limited to the use of assets and has the economic function of use control, this paper will call the property right control similar to the direct provisions of the law as "Legal suppressive Property Right Regulation", whose scope is not limited to property right use.

\subsection{Positive-Externality of Property Right and Legal Suppressive-Regulation of Property Right}

There are various ways of using property rights. Different ways of using property rights have different Positive-Externalities. Some of the Positive-Externalities are private, and the beneficiaries are limited to specific person with limited scope. For example, Zhang defined the land leased to Wang as wheat and corn planting, and the beneficiaries of the Positive-Externalities are Zhang with specific scope. Some Positive-Externalities are public, such as the bee's pollination in the process of nectar collection. The beneficiaries are the uncertain social public. Some use patterns have significant Positive-Externalities, such as the people's livelihood strategic rigid goods and materials related to national security. Based on the realization of public policy objectives, the state will set restrictions on the use of certain assets by legal means to ensure the production scale of the people's livelihood strategic rigid materials. The use control of such assets is the legal suppressive property regulation of asset use.

Take the legal restrictive control of land use as an example, in the era of agricultural civilization, land has three main functions: planting, aquaculture, animal husbandry. In the era of industrial civilization, there are some new uses for land, such as Prospecting, mining and industry. The economic value of living function has been improved unprecedentedly. In the era of urbanization, land has new commercial function, economic price of commercial function and living function grow up greatly. The planting function of land can be further divided into grain planting and cash crop planting. The different uses of land have different Positive-Externalities. Among them, the two uses of land, grain planting and cotton planting, are related to the production of clothes and foods, which are the strategic materials for people's livelihood rigid needs, with significant Positive-Externalities. The Chinese government is fully aware of these significant Positive-Externalities of land use to plant grain and cotton. In order to ensure the sustainable expansive reproduction of the people's livelihood strategic rigid needed materials, Chinese government take some regulating measures to regulate the land use, ensure the sustainable expansive reproduction of the 
people's livelihood strategic hard needed materials with the land use control.

Article 4 of the Land Management Law stipulates: The State implements a system of land use regulation. The State shall work out a general plan for the utilization of land, stipulate the use of land, and divide the land into agricultural land, construction land and unused land. Strictly limit the conversion of agricultural land to construction land, control the total amount of construction land, and implement special protection for cultivated land. ... Agricultural land refers to the land directly used for agricultural production, including cultivated land, forest land, grassland, farmland water conservancy land, breeding water surface, etc.; construction land refers to the land for building buildings and structures, including urban and rural residential and public facilities land, industrial and mining land, transportation water conservancy facilities land, tourism land, military facilities land, etc.

Agricultural land is divided into cultivated land, forest land, grassland, farmland water conservancy land and aquaculture water surface. Cultivated land is divided into permanent basic farmland and ordinary farmland. The principle of no reduction in total amount and quality of cultivated land is implemented. According to the provisions of Article 33 of the land management law, the basic farmland includes the cultivated land in the production bases of grain, cotton, oil, sugar and other important agricultural products approved and determined by the competent agricultural and rural Department of the State Council or the local people's governments at or above the county level; the cultivated land with good water conservancy and soil and water conservation facilities; the transformation plan being implemented; the medium and low yield fields that can be transformed and the high standards that have been completed Farmland; vegetable production base; agricultural scientific research; teaching field, etc.

Article 30 of the Land Management Act stipulates: The state protects cultivated land and strictly controls the conversion of cultivated land into non cultivated land. The State practices a system of compensation for the occupation of cultivated land. If the non-agricultural construction is approved to occupy cultivated land, the principle of "how much is occupied, how much is reclaimed" shall be followed.

Article 35 of the Land Management Act stipulates: After the permanent basic farmland has been demarcated according to law, no unit or individual may occupy or change its use without authorization. It is really difficult to avoid permanent basic farmland when selecting sites for key construction projects such as state energy, transportation, water conservancy and military facilities. If the land conversion or land acquisition is involved, it must be approved by the State Council.

Article 44 of the Land Management Act stipulates: The conversion of permanent basic farmland to construction land shall be approved by the State Council.

The National Land Planning Outline (2016-2030) requires that by 2020 and 2030, China's cultivated land reserved should be maintained at 1.865 billion acres of land and above 1.825 billion acres of land, which is a binding indicator, 
that is, it should be strictly implemented and cannot be broken through. In February 2019, the Central Committee of the Communist Party of China and the State Council issued Several Opinions on Adhering to the Priority Development of Agriculture and Rural areas and Doing a Good Job in the Work of "Agriculture, Rural Areas and Farmers". The opinions made it clear again that the red line of 1.8 billion acres of land of arable land should be strictly observed, the special protection system of permanent basic farmland should be fully implemented, and the permanent basic farmland should be maintained above 1.546 billion acres of land. These provisions of China's land management law and policy documents indicate that the state has set restrictions on the use of the existing farmland and permanent basic farmland in rural areas, which belongs to the "Legal suppressive Property Right Regulation" of the Suppressive-Regulation of property rights.

Use Intentional Suppressive Property Right Regulation comes from the voluntary creation of parties. This creation is called contract in law. Although the law abides by the principle of freedom of contract, the protection of freedom of contract by law is conditional rather than absolute. The contract only exists when the parties have the corresponding capacity of rights and capacity of conduct, the truth of expression of intention, content and form not violating the mandatory provisions of laws, public order and good customs (Yang, 2017). The former hand of the existing property owner can only enjoy the legal protection on the premise that it does not violate the mandatory provisions of laws and the principle of public order and good customs. Therefore, the validity of the Use Intentional Suppressive Property Right is subject to the purpose legitimacy and content legitimacy review of the judicial organ, which is not of absolute significance.

\section{Positive-Externality and Incentive-Regulation of Property Right}

The legal Suppressive-Regulation of property rights can effectively guarantees the land area scale of grain planting and cotton planting, but it can't effectively guarantee the productivity of grain and cotton in the given scale area, at the same time, due to the definition of the property right boundary, some property owners will play the property right fringing ball at the property right boundary, and the property right fringing ball will reduce the land area of grain planting and cotton planting. The property right Suppressive-Regulation policy pursues the area scale of the established production mode of property right. The fringing ball will make the land use deviate from the land use with significant positive-externality pursued by the property right Suppressive-Regulation and public policy objectives. For example, food production belongs to the farmland use Suppressive-Regulation, but there are many kinds of food, including wheat, rice, corn, beans and potatoes. If the government's public policy goal is rice and wheat, the farmers can plant beans instead of planting wheat and rice which is just the public policy goal, as a result, planting beans deviate from the public 
policy goal greatly. Planting beans does not violate the legal use Suppressive-Regulation policy, but deviates from the two public policy objectives of rice and wheat, which shows that the single property right Suppressive-Regulation can't effectively guarantee the realization of the public policy objectives. The government also needs to change the expected interests of the farmers' grain planting by incentive property right regulation, and guide its economic efforts to be consistent with the government's public policy objectives. The property rights with significant Positive-Externalities need the necessary incentive regulating measures of the government, which can effectively guarantee the sustainable expansive reproduction of the established property use mode based on the property rights Suppressive-Regulation.

\subsection{The Positive-Externalities of Property Rights and the Property Rights with Positive-Externalities are Historically Dynamic}

Some property rights have positive-externalities, different uses have different Positive-Externalities. The Positive-Externalities of property rights not only depend on the use of assets, but also on people's understanding and social development, with regional differences and time differences. In the era of agricultural civilization, grain, cotton and salt are the strategic rigid materials for people's livelihood; in the era of urbanization, housing, oil and natural gas are also the strategic rigid materials for people's livelihood. The positive-externality of the people's Livelihood Strategy for the use of property rights is also subject to the level of understanding and social problems in a specific era. After the outbreak of SARS and 2019-nCoV, medical masks have become just needed materials for people's Livelihood Strategy. After the economic development and the improvement of the living standards, edible oil, beef, pork and mutton have become the Strategic just need materials of people's livelihood in different countries and regions. Among the many uses of land, the grain and cotton planting uses of land have significant Positive-Externalities. Food is the most important thing for the people. The grain planting use of land can effectively guarantee the people's need to eat, it is just the Positive-Externalities of the land for grain planting. The Chinese government is fully aware of the significant Positive-Externalities of land and grain cultivation, and has always attached great importance to the control and incentive of land and grain cultivation. The first document of the Central Committee of the people's Republic of China over the years focuses on agricultural issues, especially grain cultivation. After industrialization and urbanization, the population is concentrated in the city. Edible oil, natural gas and oil have gradually become the strategic materials for people's livelihood in the new era. People's livelihood strategy needs to be the positive-externality of these property rights. The Chinese government has incorporated pork into the national strategic reserve materials according to the consumption habits of residents, and the pig industry has also become an industry with significant positive-externality. 


\subsection{Incentive-Regulation Does Not Necessarily Have the Effect of Promoting Sustainable Reproduction of Property Right Production Mode with Significant Positive-Externalities}

Although the grain planting use of land has a significant positive-externality, the positive-externality lacks controllability and measurability, which does not necessarily bring corresponding returns to the property owner. Under the established productivity level, production mode and resource distribution pattern, the grain planting use of land may not bring sufficient market profits to the property owner, and the production and management of strategic materials for people's livelihood, the necessary sustainable inputs may not be available. Taking grain as an example, for a long time, the characteristics of China's rural grain production are intensive cultivation and small-scale production and management. Jiangsu has cultivated 0.86 acre of land per capita, 1.42 acre of land per capita in rural areas, and the family of five people is about 7 acre of land. The grain production implements the double cropping system of rice and wheat, which is about 600 $\mathrm{Kg}$. for one acre of rice, $300 \mathrm{Kg}$. for wheat, $900 \mathrm{Kg}$. for one acre of rice and wheat, and $6300 \mathrm{Kg}$. for seven acres of land The market price is less than 16,380 yuan when calculated by 1.3 yuan $/ \mathrm{Kg}$.; when a laborer goes out to work, the average monthly price is 3000 yuan, and the annual price is not less than 36,000 yuan, plus the social insurance income, about 45,000 yuan, planting rice requires pesticide, fertilizer and irrigation, and the average cash cost per acre of wheat is 520.75 yuan, and the average cash cost per acre of rice is 622.44 yuan (Luo, 2017), a total of 1143 yuan/acre, excluding the cost of agricultural materials 8000 yuan, the income from grain planting is only 8000 yuan. As a result, the grain planting industry mainly relies on the "3860 troops" in the countryside, that is, the elderly and women, the male labor force go out to work more, and even some parts of the land are barren.

In the face of market failure, the government adopts the means of financial payment transfer for the production of strategic materials for people's livelihood with significant Positive-Externalities, and gives economic incentives to relevant parties by means of financial payment transfer, which is called Incentive-Regulation, use Incentive-Regulation measures to improve the economic interests of the parties, to promote private economic efforts to generate private income as close as possible to social income. To encourage farmers to use land for food production by means of financial payment transfer will generate economic incentives for food production, but it does not necessarily lead to the incentive effect of sustainable expansive food production. To produce the incentive effect of sustainable expansive food production, the Incentive-Regulation need a premise, that is the Incentive-Regulation measures need to be Legalization, and given farmers the Sufficient quantity and reliable good expectation, otherwise the incentive effect will be interrupted at any time. Taking grain production as an example, from 1980 to 1982, the average increase in grain production was 2.5383 million tons, and in 1984, China's grain production reached a periodic 
peak of 40 million tons; in 1985, the production was greatly reduced, $6.92 \%$ lower than that in 1984, and only in 1989 did it recover to the level of grain production in 1984. How can grain output rise and fall greatly? The price policy of agricultural products is the most important institutional reason. The institutional reason for the sharp increase of grain output from 1980 to 1982 is that the government has raised the purchase price of grain for three consecutive years, by $49 \%$. The increasing purchase price is the economic incentive given by the government to grain planting, which belongs to the category of Incentive-Regulation. The sharp increase of grain output in 1984 did not bring corresponding benefits to farmers. The "difficulty of selling grain" appeared in this year, which damped farmers' enthusiasm. This is because the rise of grain purchase price and the large increase in grain production needs the corresponding increase of the government's purchasing power, but the corresponding increase of the government's purchasing power lacks the necessary institutional guarantee at that time. The original Incentive-Regulation lacks Legal rigidity, belongs to the category of temporary Incentive-Regulation. It can't bring the sustainable and reliable good expectation to the relevant property owners, and the Incentive-Regulation can't motivate the property owners of agricultural land sustainably grain planting enthusiasm. In 1985, the agricultural tax was reformed from the collection of grain to the collection of cash in lieu. At the same time, the dual track system of grain price was implemented. Grain purchase was priced according to the ratio of " $3: 7$ ", that is, $30 \%$ of the original unified purchase price and $70 \%$ of the original over purchase price. These two reforms substantially reduced the purchase price of agricultural products. In addition, the "difficulty in selling grain" in 1984, farmers adjusted the planting structure greatly, and grain production has given way to cash crops, resulting in a comprehensive decline in the total and per unit yield of grain (Lin \& Yu, 2006). This shows that the continuous adjustment of economic incentive policy not only does not bring the reliable good expectation of grain planting to the landowners, on the contrary, the expectation of loss is constantly strengthened. The use of agricultural land is completely handed over to the market for regulation, and the market fails to give the landowners the necessary stable benefit return, resulting in the landowners' adjustment of land use, which is the institutional reason for the continuous decline of grain production. After 2004, China's grain output has entered a stage of continuous increase, and returned to the level of 500 million tons in 2007. In 2013, the grain output has reached a stage high of 60 million tons, The grain output has achieved "ten consecutive increases". we analyze that the important institutional reasons lie in the "three agricultural subsidies" successively implemented in 2004, such as grain direct subsidy, fine seed subsidy and agricultural machinery subsidy, as well as the "Dynamic Adjustment Mechanism of Agricultural Material Comprehensive Subsidy Linked to the Price Rise of Agricultural Means of Production" established by the Decision of the CPC Central Committee on Several Major Issues Concerning the Promotion of 
Rural Reform and Development (2008) and the total abolition of agricultural taxes in 2006. In December 2003, the Central Committee of the Communist Party of China and the State Council issued the Opinions on Several Policies to Promote the Increase of Farmers Income, stipulating that direct subsidies should be given to grain farmers, certain subsidies should be given to large-scale agricultural machines and tools, and good seed subsidies should be given to grains such as wheat and soybean. All localities should ensure that the subsidy funds are actually put into the hands of farmers. Since 2004, Jiangsu Province has uniformly subsidized 20 yuan per acre according to the actual planting area of rice, 69 yuan/acre in 2010 and 103.5 yuan/acre in 2014. The agricultural subsidy standard implements the policy of steady and rising, that is, it is not lower than the base number of the selected year. With the price change, the subsidy standard correspondingly rises, which has a strong impact on the weight of the interests of the agricultural land property owner in the interest collection of the agricultural land property owner. The issuance of opinions on policies to promote farmers' income increase marks the institutionalization of "three agricultural subsidies" and the stable and sustainable institutional support for the economic incentive of agricultural land grain planting. Its value lies in the establishment of a sustainable and guaranteed reliable good rather than a reliable loss expectation for the relevant property owners, it is a guaranteed and sustainable reliable benefit good expectation that has encouraged the relevant property owners to expand the reproduction of grain planting industry, which has become a profitable business.

\subsection{The Legal Incentive Regulation with Sufficient Benefits Can Effectively Correct the Market Failure of Property Right Production Mode with Significant Positive-Externalities, and Effectively Promote the Sustainable Expansive Reproduction of Property Rights Production Mode with Significant Positive-Externalities}

The government's land-based grain cultivation has the significant positive-externalities of the production of grain, which is the livelihood strategy and just needed materials. It gives the landowners stable and sustainable legal economic incentives. It is expected that through the legalization and entitlement of these economic incentives, the stable and sustainable reliable interests of the landowners can be expected, and the interests structure of the landowners can be effectively changed and induced our economic efforts are in line with the government's expectations. The essence of these legal economic incentives is to give the subject of property rights the right to claim administrative payment from the government according to legal standards and legal procedures, which is manifested in the public rights of citizens to the government in the modern legal society. Legal economic incentive has the remarkable function of macroeconomic regulation and control, and is an important public policy tool to achieve the goal of government public policy. In this paper, the economic incentive that the gov- 
ernment attaches to specific property rights to strengthen specific purposes is called Incentive-Regulation, and the economic incentive that the government has attached and institutionalized is called legal incentive property rights, which is an important part of property rights.

People's understanding of the externality of assets and its importance in the development of national economy and society is constantly changing. The international economic environment is also constantly changing. Therefore, the legal incentive property rights of specific assets are also constantly changing. Therefore, the types and scope of legal incentive property rights are also historically dynamic. For example, after China's accession to the WTO, the original "three agricultural subsidies" gradually do not conform to the WTO rules. The original "three agricultural subsidies" began to reform in 2015. The guiding opinions on adjusting and improving the three agricultural subsidies combine the original "three agricultural subsidies" into "agricultural support and protection subsidies". The "agricultural support and protection subsidies" are divided into supporting farmland and land conservation subsidies and grain subsidies for moderate scale operation. Article 2 of the measures for the administration of subsidies for agricultural support and protection issued by the Ministry of agriculture in December 2018 stipulates that "the subsidies for agricultural support and protection are the special transfer payment funds arranged by the public budget of the central government, which are used to support the protection of farmland and land capacity and the moderate scale operation of grain, as well as other directions determined by national policies." Article 5 stipulates: "the subsidy for agricultural support and protection is used for the fund for the protection of the land capacity of cultivated land. In principle, the object of the subsidy is the farmers who have the contract right of cultivated land. The funds used for moderate scale operation of grain shall be subsidized to moderate scale producers and operators of grain, focusing on new business and service subjects such as large grain farmers, family farms, farmers' cooperatives and agricultural socialized service organizations." Grain moderate scale management subsidy is a new economic incentive measure for rural land agricultural moderate scale management. It is an agricultural production mode guidance based on the characteristics of China's extensive agricultural development mode and small business scale. For example, in 2019, the subsidy standard for agricultural support and protection in Jiangsu Province (cultivated land capacity protection) is $120 \mathrm{yu}$ an/acre, which is equivalent to 20 yuan/acre in Jiangsu Province 14 years of comprehensive subsidies for agricultural materials and improved varieties. In 2017, the grain output reached 617.9 billion $\mathrm{Kg}$., an increase of $3.6 \mathrm{~kg} / \mathrm{acre}$ compared with 2016, an increase of $1.0 \%$, reaching a historical high point. On the premise that the cultivated land area has been reduced year by year, the grain output has continued to rise for 13 consecutive years. This shows that the legal incentive property right has sufficient economic incentive to the owner of agricultural land, greatly adjusts the interest weight of grain planting in the interest collection of the owner of agricultural land, effectively stimulates the enthusiasm 
of the owner of agricultural land for grain planting and sustainably expands the input of reproduction.

China implements market economy, the market is the basic means of resource allocation. However, the market has the situation that some goods and services with significant Positive-Externalities are unable to allocate resources effectively, which is called "market failure" in academic circles. In the 70 years since the founding of the People's Republic of China, the market economy efficiency of grain planting industry is much lower. As far as the achieving of stable and sustainable growth of grain planting industry was concerned, grain planting can't rely on the spontaneous resource allocation of the market. Grain planting industry can only rely on financial payment transfer to change the yield of grain planting industry. In the era of rule by law, the transfer of financial payment must be legalized to correct market failure. The legalization of financial payment transfer of grain planting industry is to realize the type adjustment and unified adjustment of grain planting relations, legalization of beneficiary subjects, legalization of beneficiary standards and legalization of beneficiary procedures. The essence of the original three agricultural subsidies is to give farmers within the scope of legal planting industry the right to claim for legal administrative payment according to legal standards and procedures, and the agricultural administrative department has the legal obligation to pay legal administrative payment according to legal standards and procedures. The three agricultural subsidies have effectively changed the interest structure of agricultural producers and adjusted the input of grain planting industry. Its institutional performance is to achieve sustainable growth of grain production. Therefore, the legal incentive of property rights has a significant market public policy tool function. Although the change of China's agricultural land use incentive policy has the background of WTO Anti Subsidy Rules, the "agricultural support and protection subsidy" is different from the "three agricultural subsidies", especially the incentive fund for supporting the protection of farmland's land force, which more precisely shows the incentive nature of the incentive fund for the use of farmland and the nature of the appropriate scale management mode of farmland, indicating that the incentive property right includes two parts, one is the institutionalized legal incentive property rights; the other is the legal incentive property rights that are not defined but may be given in the future. The specific types and scope of legal incentive property rights are created by the government according to their own political, economic and social resources, as well as the understanding of the importance of related industries, so they are legal, regional differences and historical dynamics.

\section{Conclusion: We Should Pay Adequate Attention to Positive-Externality, Accurately Create and Apply Property Right Regulation}

The research of this paper shows that both the statutory restraining regulation and the statutory Incentive-Regulation are applicable to the economic efforts 
with Positive-Externalities, and they are indispensable. Taking the grain production use of land as an example, the production of grain, which is just needed for people's livelihood strategy, is a significant positive-externality of the land grain planting use. This positive-externality is rooted in the land grain planting use. Based on the understanding of the positive-externality of the agricultural land grain planting use, the State takes the stable growth of grain production quality as the public policy goal, what we pursue is the absolute growth in grain production. The public policy goal of grain production is the national grain security, which is highly consistent with the positive-externality of agricultural land for grain cultivation. In order to maximize the public policy goal of grain production, the Chinese government, on the one hand, implements the property right restraining control of land use limited to cultivated land and grain planting industry, so as to ensure the input scale of cultivated land for grain production; On the other hand, we should give farmland land capacity subsidies and appropriate scale management subsidies to ensure the input scale of labor force, production tools and agricultural materials other than grain production farmland elements.

In terms of the legal suppressive property right regulation of cultivated land for grain planting, firstly, the land for grain production is divided into agricultural land, agricultural land is divided into cultivated land, forest land, grassland, farmland water conservancy land and aquaculture water surface, and cultivated land is divided into permanent basic farmland and ordinary farmland. The essence of special protection of cultivated land is to realize the purpose of the land public policy, that is to keep the red line of 1.8 billion acres of cultivated land, which is the recognition and utilization of the positive-externality of land and grain cultivation. The experience here is the accuracy of the object of the control of the inhibitory property right. The government divides the land into ordinary land and permanent land according to the different uses of the Positive-Externalities, and further subdivides the land with the most strategic value for people's livelihood into ordinary land and permanent land. The strength is reflected in the unified return of the decision-making power of the use change of permanent land to the State Council, and the implementation of strict suppressive property right regulating measures. The rule by law is embodied in the legalization of land use Suppressive-Regulation and regulating strength, and the formulation of Land Management Act of the people's Republic of China.

As far as the legal incentive property right regulation of cultivated land grain planting uses is concerned, grain production has experienced many twists and turns. Every big fall of grain production is bound to be accompanied by greater economic incentives for grain production. After several exchanges, finally, the Chinese government gives institutionalized land protection subsidies to the grain planting uses of land, and appropriate regulations for improving agricultural productivity and international competitiveness The mode of operation gives the institutionalized grain moderate scale operation subsidies, endows the landowner with the administrative payment claim right to request the legal economic incentives according to the legal standards and procedures, and endows 
the government with the administrative payment obligation to pay the legal economic incentives according to the legal standards and procedures. The government's incentive control measures for agricultural land economy not only realize the rule of law, but more importantly, the scale of economic incentive implements the stable and sustainable increase policy linked with price fluctuation. The standard of legal economic incentive is enough to affect the interest structure of the property owner of agricultural land, and promote the property owner of agricultural land to choose grain production and appropriate scale operation voluntarily and consciously, which is also a kind of land grain Understanding and utilization of Positive-Externalities of plant use. The experience here is that the object of legal incentive control is accurate, and the land capacity of cultivated land and the management mode of improving agricultural productivity are accurate. The legal incentive property right control measures are to give land capacity subsidies per acre according to the land area used for grain production and appropriate scale economic subsidies per acre, and the appropriate scale is set as 100 acre. The strength is reflected in the land capacity subsidies and appropriate scale of cultivated land The scale of business subsidies, such as moderate scale business subsidies, has many ways, among which loan discount is one way, and the intensity of loan discount is $50 \%$ of the interest; the rule of law is reflected in the formulation and promulgation of the subsidy standards, procedures, highly specific and determined measures for the management of agricultural support and protection subsidy funds.

We believe that we should fully understand and attach great importance to the Positive-Externalities of property rights, set up necessary legal suppressive regulating methods for property rights with significant Positive-Externalities, so as to ensure the production scale of corresponding property rights; set up legal incentive regulating methods for property rights with significant Positive-Externalities, so as to ensure the necessary input of corresponding property rights production methods, We should pay attention to the accuracy, that is target accuracy, strength accuracy and legalization of regulation measures, neither too abstract nor too concrete, and implement precise policies, otherwise it may lead to the precipice fall of grain production in 1985 and 2000.

\section{Conflicts of Interest}

The authors declare no conflicts of interest regarding the publication of this paper.

\section{References}

Barzel (1997). Economic Analysis of Property Rights (p. 2), Shanghai: Sanlian Bookstore.

Dou, Z. J., \& Li, S. L. (2017). Issue Research on Government Incentive Regulation in the Development of New Energy Industry. Modern Commerce, 1, 265-266.

Feng, J. C. (2017). Ownership, Transfer Cost and Environmental Regulation: Empirical Evidence from Chongqing Micro Enterprises. Finance \& Trade Economics, 4, 21-36.

Ji, X. Q. (2010). Economic System, Property Right Structure and Economic Performance: General 
Framework. Jiangsu Social Sciences, 1, 59-64.

Lin, Y., \& Yu, L. (2006). Analysis of the Fluctuation of China's Grain Output. Journal of Jilin Agricultural University, 3, 346-350.

Luo, P. (2016). The Production Cost of Agricultural Products in Jiangsu Increased, and Farmers' Money Bags Became Thinner in 2016.

http://news.jschina.com.cn/focus/201706/t20170616_658673.shtml

Michael, D. B. (1996). Principles of Law: An Analysis of Norms (pp. 98-100, 101, 102, 103-104). Beijing: China Encyclopedia Press.

Tian, S. Y. (2010). Forest Resource Control Policy Research after Collective Forest Right Reform. Agricultural Economic Issues, 1, 90-95.

Yang, L. X. (2017). Conflict and Specific Application of the Effectiveness Rules of Legal Acts in Civil Affairs in China. Journal of Gansu University of Political Science and Law, 5, 1-12.

Zhang, L. X., \& Zhang, X. C. (2011). Industrial Safety and Government Regulation in Key Links of Agricultural Industry Chain. Teaching and Research, 2, 15-21. 